\title{
Long-Term Ripening Evaluation of Ewes' Cheeses by Fourier-Transformed Infrared Spectroscopy under Real Industrial Conditions
}

\section{Jonathan Andrade (D), Cristina Guimarães Pereira, Thamiris Ranquine, Cosme Antonio Azarias, Maria José Valenzuela Bell, and Virgilio de Carvalho dos Anjos}

Grupo de Engenharia e Espectroscopia de Materiais, Departamento de Física, Universidade Federal de Juiz de Fora, Rua José Lourenço Kelmer s/n São Pedro, 36036-900 Juiz de Fora, MG, Brazil

Correspondence should be addressed to Jonathan Andrade; dr.andradej@gmail.com

Received 30 October 2017; Revised 23 January 2018; Accepted 5 February 2018; Published 25 March 2018

Academic Editor: Jose S. Camara

Copyright ( 2018 Jonathan Andrade et al. This is an open access article distributed under the Creative Commons Attribution License, which permits unrestricted use, distribution, and reproduction in any medium, provided the original work is properly cited.

\begin{abstract}
The ripening changes over time of special cheeses (Pecorino, ewes' ripe, and Gouda) made with ewes' milk were evaluated using FTIR/ATR spectroscopy during approximately one year. The midinfrared FTIR/ATR analyses were carried out in different ripening times between the cheese varieties and processed by means of multivariate statistical approaches. Overall, during the maturation, we observed a downward trend of the absorbance intensity of the amide group peaks (1700 to $1500 \mathrm{~cm}^{-1}$ ), which is linked to the breakdown of peptide bonds. Similar behavior was obtained for the lipidic region (3000 to $2800 \mathrm{~cm}^{-1}$ and 1765 to $1730 \mathrm{~cm}^{-1}$ ). Hierarchical cluster analysis and principal component analysis allowed the evaluation of the physicochemical changes of the cheeses. The proteolysis occurs in a fast pace during the first trimester of the ripening process, and the lipids are converted to smaller species as the times goes by. Our results indicate that infrared spectroscopy can be a useful tool in determining optimal temporal parameters in stages involving the development, production, and even a possible estimation of shelf life of cheeses.
\end{abstract}

\section{Introduction}

Cheese is the most abundant processed dairy product in the world. The global production is around 23 million tons, representing an increase of 791,000 tons between 2013 and 2014 [1]. The United States, for example, was responsible for approximately a quarter of the world production in 2014 and expected to reach 286,000 tons in export trades by the end of $2017[1,2]$. Thus, the quality control of cheeses is of great importance, especially when a long period of ripening is required before marketing the product. About $70 \%$ of the total milk produced in Brazil is processed into cheeses, where approximately 1100 tons are consumed within the domestic market per year. The special cheese market is growing throughout the years, as well as the research and development of products adapted for the Brazilian market [3].
The physical-chemical and sensorial characteristics of dairy products can be changed by several factors including herd genetics, health, feeding, and environmental conditions, among others [4]. Cheese ripening involves several biochemical reactions, leading to the development of the unique sensorial attributes for each cheese variety [5-10]. The formation of smaller peptides and free amino acids has a direct impact on flavor and texture, due to the breakdown of the protein network [7]. In addition to that, lipolysis generates free fatty acids and organic acids that are further metabolized to volatile and nonvolatile flavor components [11].

Usual methods for analyzing cheese composition and ripening index are time-consuming and expensive. There is a need for new methodologies and instrumentation to observe the main changes during the ripening process. In 
fact, nowadays, several noninvasive spectroscopic techniques have gained more and more space due to several reasons: (i) they are environmentally friendly due to the absence of reagents; (ii) they are fast due to the absence of sample preparation; and (iii) they are susceptible to miniaturization [12-15]. In particular, instrumental technique such as midinfrared (MIR) spectroscopy has been widely used in the analysis of food products [16]. Encompassing the spectral range of 4000 to $400 \mathrm{~cm}^{-1}$, MIR spectroscopy allows access to the vibrational modes of the samples which may result in bands that are assigned to specific chemical groups. In 2005, AOAC international has approved the Fourier transform infrared (FTIR) method for determination of fat, protein, lactose, and total solid contents in some dairy products [17]. Since then, studies on cheese ripening using spectroscopic methods have been published [18-23]. However, they were all carried out during a relatively short period of time, that is, less than 3 months. A better exploration of the maturation time requires a longer period of analysis, once the development of sensory attributes such as texture and flavor is directly related to the rate of breakdown of the casein matrix over time, especially in hard and semihard-type cheeses [11].

This paper deals with three ewes' cheeses under real industrial conditions and named "Pecorino," "Gouda," and "ewes' ripe." Although present in the European and North American markets, the "Pecorino" and "Sheep Gouda," the information about ewes' cheeses are in general scarce [24]. Concerning Brazil, the three cheeses are promising novelties in the market, especially the "ewes' ripe," as it is a variation of "Minas" cheese (made originally with cow's milk). To evaluate them, attenuated total reflection (ATR) unit was coupled to FTIR spectrometer to follow the changes in the cheeses over a long period (approximately one year). As a result, we show that infrared spectroscopy provides secure hints to determine optimal temporal parameters in ripening stages involving the development of the aforementioned cheeses.

\section{Material and Methods}

2.1. Cheese Samples. A dairy industry with Brazilian federal inspection seal (SIF), located in the municipality of Soledade de Minas, Minas Gerais, Brazil, supplied three different varieties of cheese (Pecorino, Gouda, and ewes' ripe) made with ewes' milk. The cheeses had different production dates and at aging times ( 1 to 12 months), so that represents real industrial process conditions.

2.2. Cheese Composition. The compositions of the supplied cheeses were carried out in terms of moisture, fat, and protein content to classify them according to the Brazilian legislation. The measurements were carried out following Lutz [25] and Brasil [26], which establish the physical and chemical official analytical methods for control of milk and dairy products. All samples were tested in duplicate.

2.3. FTIR/ATR Spectroscopy Measurements. Infrared spectroscopy was performed using a FT-MIR spectrophotometer (Bruker, model Vertex 70), with ATR accessory and OPUS 6.5 software. Infrared spectra were recorded in absorbance
TABle 1: Physicochemical characterization of Pecorino (2nd month), Gouda (2nd month), and ewes' ripe (1st month) cheeses. Values obtained from duplicates and expressed as percentages \pm standard deviation.

\begin{tabular}{|c|c|c|c|}
\hline Cheese & Moisture (\%) & $\begin{array}{c}\text { Total } \\
\text { protein }(\%)\end{array}$ & FDM (\%) \\
\hline Pecorino (2 months* $)$ & $27.6 \pm 0.1^{\mathrm{a}}$ & $26.886 \pm 0.1^{\mathrm{a}}$ & $53.5 \pm 0.4^{\mathrm{a}}$ \\
\hline Gouda (2 months*) & $36.0 \pm 0.0^{\mathrm{b}}$ & $19.916 \pm 0.1^{\mathrm{b}}$ & $58.2 \pm 0.4^{\mathrm{b}}$ \\
\hline Ewes' ripe (1 month*) & $43.0 \pm 0.1^{c}$ & $21.936 \pm 0.1^{\mathrm{c}}$ & $56.2 \pm 0.0^{\mathrm{c}}$ \\
\hline$p$ value & $0.004494^{* *}$ & $0.000001^{* *}$ & $0.000000^{* *}$ \\
\hline
\end{tabular}

FDM: fat in dry matter. Superscript letters were used to indicate the group classification. ${ }^{*}$ Ripening time. ${ }^{* *}$ Means without a common letter are significantly different $(p \leq 0.05)$.

mode, between 4000 and $400 \mathrm{~cm}^{-1}$, with a resolution of $4 \mathrm{~cm}^{-1}$ and 32 scans accumulated by sample. The data were analyzed in the software OriginPro 8.0, Excel, and Minitab.

Cheese slices were prepared with approximately $4 \mathrm{~cm}^{2}$ of area and thickness of $1 \mathrm{~cm}$. The samples were taken from the center of the cheeses to avoid any contamination during the storage time. The measurements were performed in quadruplicate, using two pieces of each cheese.

2.4. Statistical Analysis. The differences in group mean values were submitted to analysis of variance (one-way ANOVA). Tukey HSD test was carried out when significant differences among groups were obtained. The statistical tests were performed with a significance level equals to $5 \%$ using Statistica 7.1 software. The spectra obtained between 3000 and $2800 \mathrm{~cm}^{-1}, 1766$ and $1730 \mathrm{~cm}^{-1}$, and 1700 and $1000 \mathrm{~cm}^{-1}$ were submitted to multivariate analysis using Minitab 16.1.1 software. Hierarchical cluster analysis (HCA) was performed with different linkage methods (data not shown), where the clustering using the McQuitty linkage provided the best overview of the results. Finally, the principal component analysis (PCA) was applied to the spectral sets to evaluate the evolution during ripening.

\section{Results and Discussion}

3.1. Physical-Chemical Characterization of the Cheeses. The earliest stage of maturation of each cheese received, that is Pecorino (2nd month), Gouda (2nd month), and ewes' ripe (1st month), was submitted to physical-chemical analysis to estimate values of moisture, total protein, and fat in dry matter (FDM) as presented in Table 1. All cheese samples were classified as "fatty" since their FDM values were between $45.0 \%$ and $59.9 \%$. In relation to moisture, the Pecorino cheese revealed being the variety with the lowest value, "hard," while ewes' ripe and Gouda were classified as "average moisture" or "semihard" [27]. Moisture values were within the allowed range according to the local regulation [26]. Analysis of variance revealed that the cheeses presented significant difference between them, regarding the above parameters.

3.2. FTIR/ATR-MIR Spectroscopy. Figure 1 shows the absorption spectra of Pecorino (a), Gouda (b), and ewes' ripe (c) 


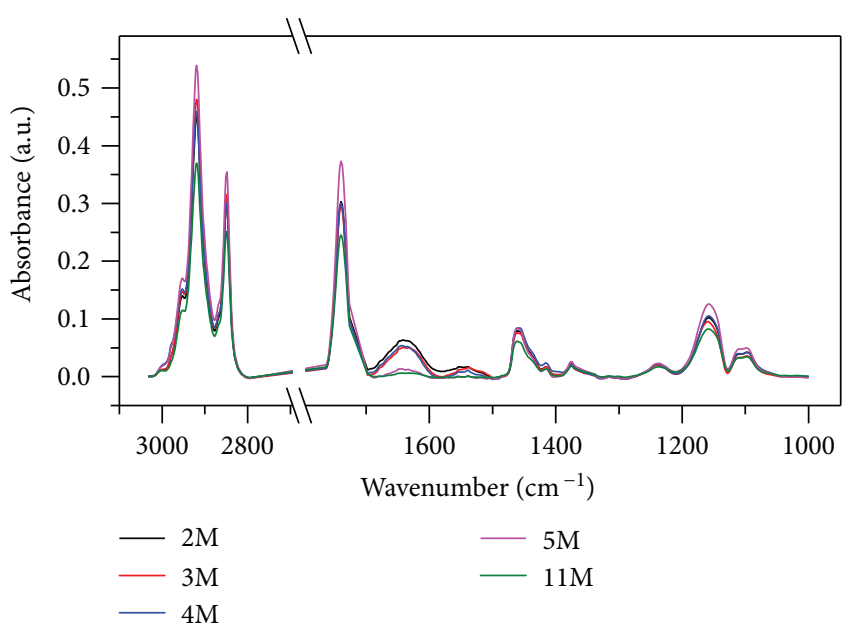

(a)

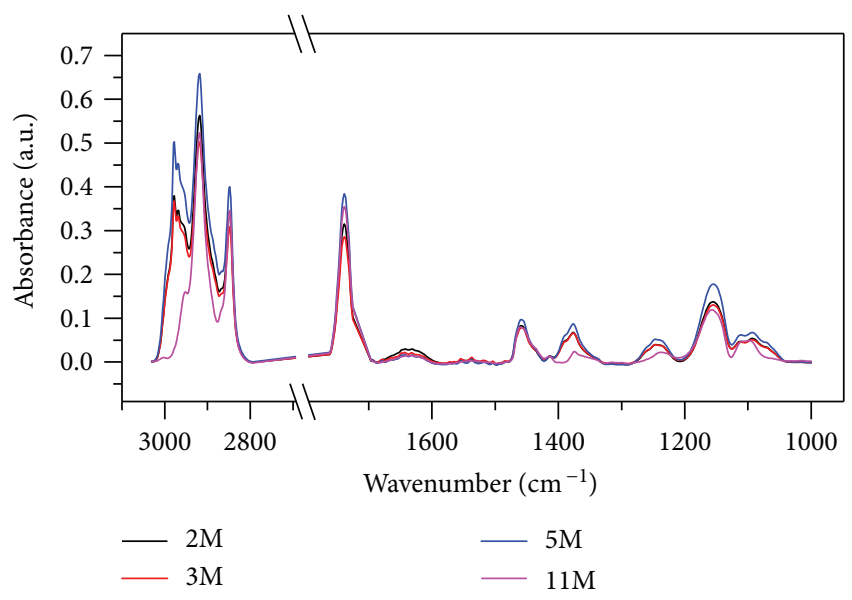

(b)

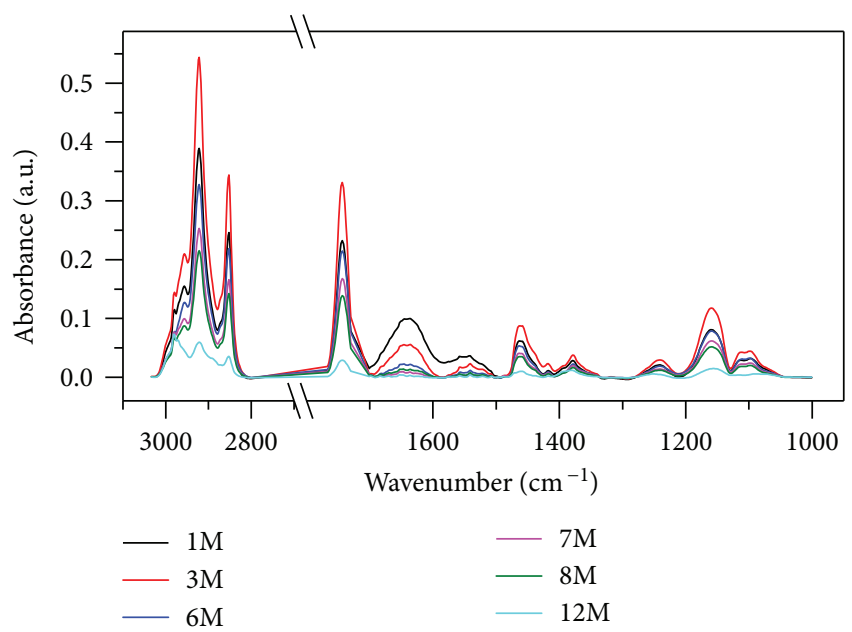

(c)

FIGURE 1: Fourier transform infrared spectra $\left(3700\right.$ to $\left.1000 \mathrm{~cm}^{-1}\right)$ of Pecorino (a), Gouda (b), and ewes' ripe (c) cheese samples during ripening. M: months.

cheeses over some months (M). In general, for all samples, the spectra presented bands around the same spectral positions which, nevertheless, differ in intensity a priori as well as along the time. The difference in intensity per se is related to the nature of the cheese and is weighted to different functional groups $[20,28,29]$. The differences along the time have their origins linked to the biochemical processes occurring during ripening.

The biochemistry of the cheese ripening is usually evaluated under three general subjects: proteolysis, lipolysis, and glycolysis [11, 30]. Among these processes, the first two are considered the most important for the great majority of the matured cheeses [5-10]. Therefore, the spectra were subdivided in narrow regions, to ease the interpretation of the data over time. These regions were conveniently handled by multivariate statistical analysis.

3.2.1. Amide I and II Region. The area between 1700 and $1500 \mathrm{~cm}^{-1}$ are related to peptide bonds $(\mathrm{CO}-\mathrm{NH})$, representing two major peaks: amide $\mathrm{I}$ in $1640 \mathrm{~cm}^{-1}(\nu \mathrm{C}=\mathrm{O}, v \mathrm{C}-\mathrm{N})$ and amide II in $1550 \mathrm{~cm}^{-1}(\delta \mathrm{N}-\mathrm{H}, v \mathrm{C}-\mathrm{N})[29,31]$. The behavior of these peaks during the ripening processes of the three types of cheese can be observed in Figure 2.

In general, all varieties studied have shown a decrease in the absorbance in both bands during the development of the ripening process. This indicates the occurrence of the hydrolysis of proteins by breakdown of the peptide bonds. This conclusion is supported by Fox et al. [6].

Martín-del-Campo et al. [29] have used midinfrared spectroscopy to study the ripening phenomena of two cheese zones (core and under-rind) of Camembert cheeses. Significant changes were recorded for amide I and II bands in the under-rind and only for amide II in the core. The maturation time analyzed was of 27 days where the absorbance values decreased until the tenth day and then tended to increase up to the end of the maturation. Mazerolles et al. [32] studied sixteen experimental semihard cheeses in the range of amide I and II at 1, 21, 51, and 81 days of maturation. Their results have shown a continuous decrease in the amide I band and an increase of amide II.

In Figure 2, one can observe that even though the absorbance intensities have decreased systematically over-ripening time, they do not occur in the same way among the cheese varieties analyzed and not with the same rate in the months of ripening. Regarding the Pecorino cheese (Figure 2(a)), the highest variation in absorbance levels (linked to proteolysis) appeared in the months between 4 and 5 of the maturation process. In ewes' ripe cheeses (Figure 2(c)), this fact could be verified in the months between 1 and 3 , while in Gouda cheeses (Figure 2(b)), the proteolysis seemed to happen in a more constant pace, meaning that the variations among the months were similar up to the 5th month. The difference in the intensity decay of the peaks could be explained by the fact that the casein hydrolysis (proteolysis), lipid hydrolysis (lipolysis), and lactose fermentation processes are dependent on the milk composition, the fabrication process, $\mathrm{pH}$, salt content, water activity, storage temperature, and specially, the type of yeast present in the cheese $[8,11,30]$.

Studies evaluating the amide peaks in cheeses have stated that changes in the intensity of the amide I peak might be associated with modification in the secondary structure of casein, protein aggregation, and protein/water interaction 


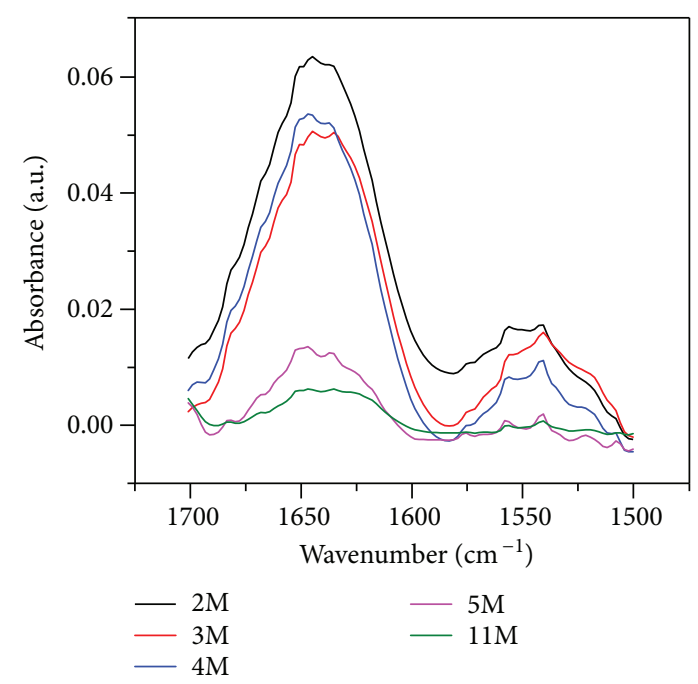

(a)

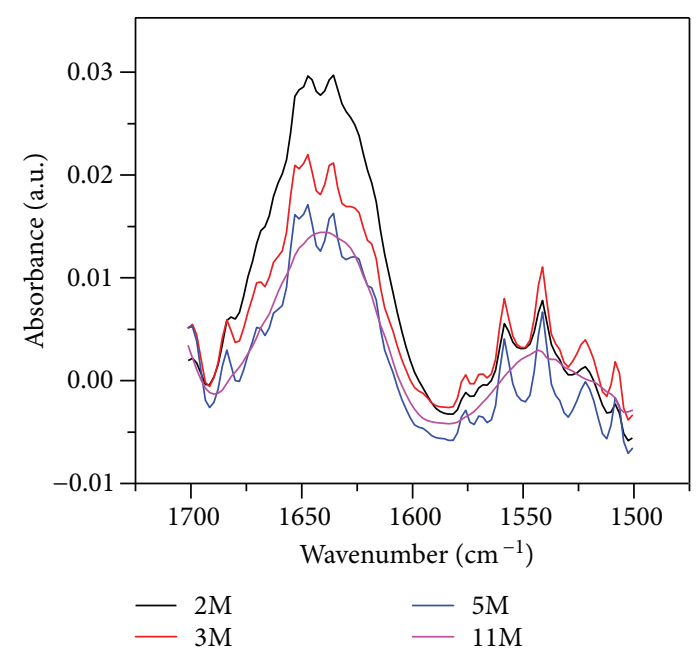

(b)

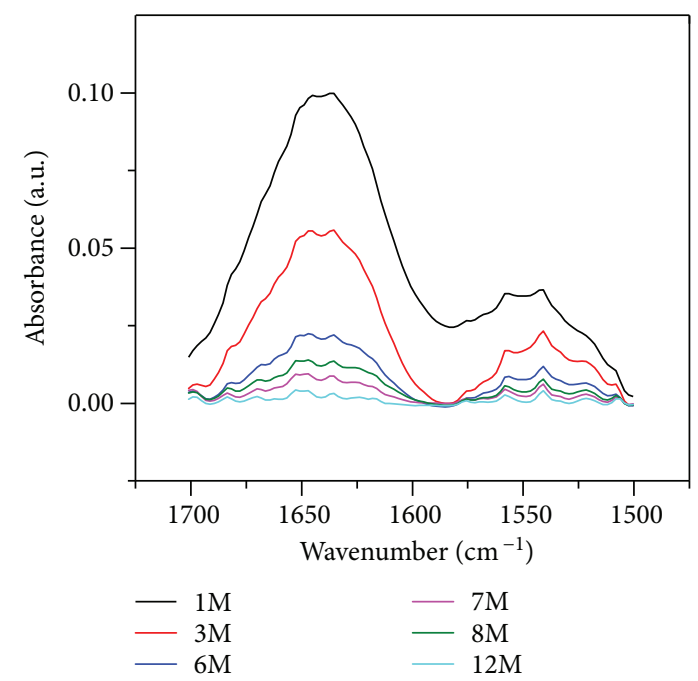

(c)

FIGURE 2: Fourier transform infrared spectra $\left(1700\right.$ to $\left.1500 \mathrm{~cm}^{-1}\right)$ of Pecorino (a), Gouda (b), and ewes' ripe (c) cheese samples during ripening. M: months.

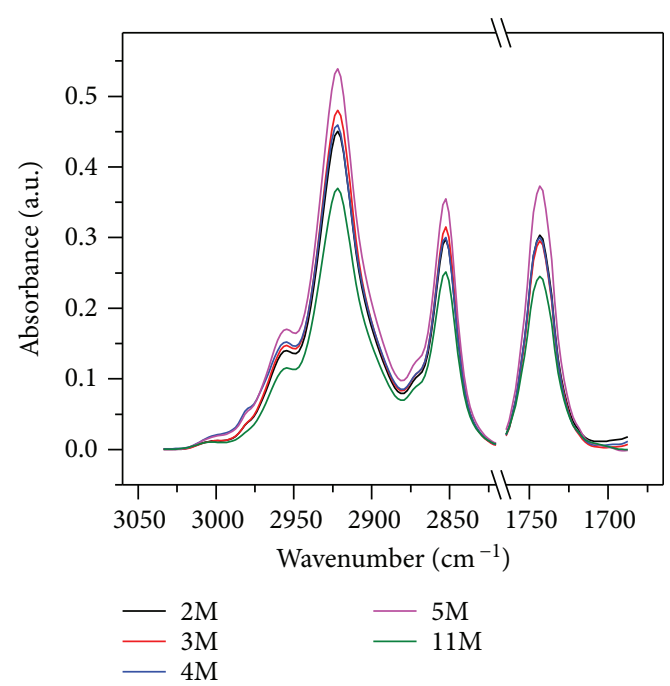

(a)
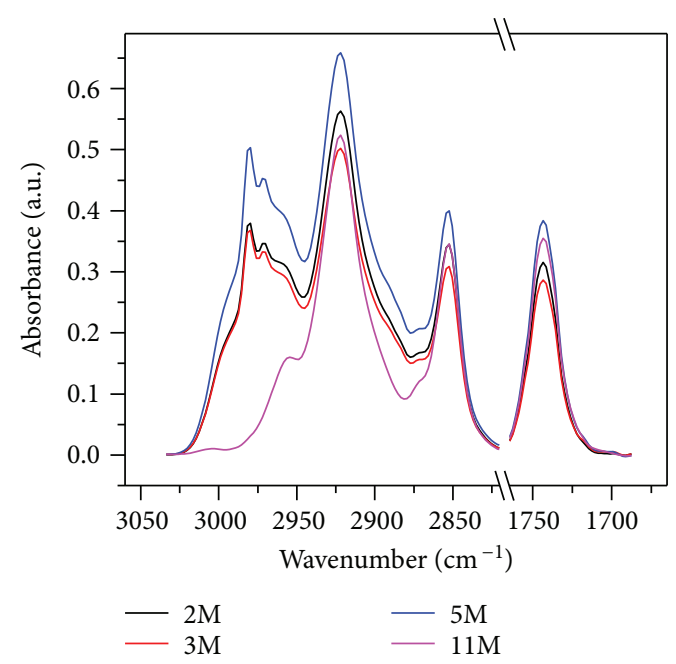

(b)

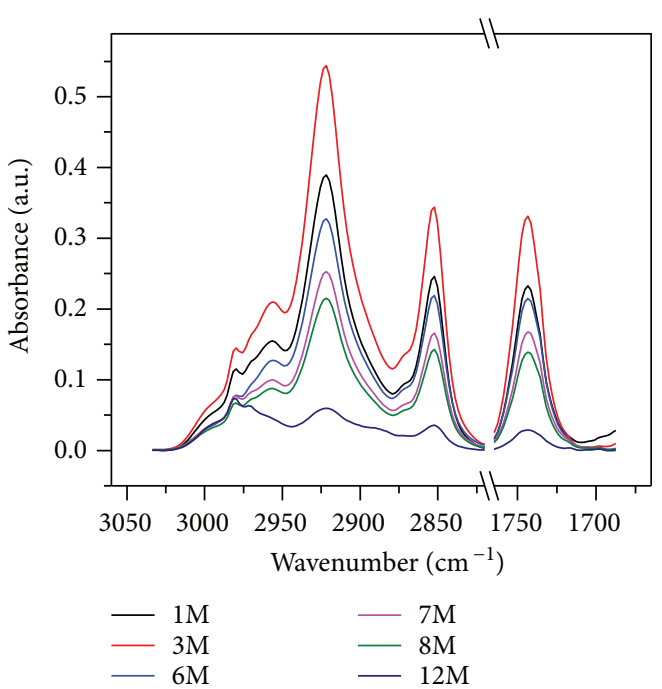

(c)

FIgURE 3: Fourier transform infrared spectra (3000 to $2800 \mathrm{~cm}^{-1}$ and 1765 to $1730 \mathrm{~cm}^{-1}$ ) of Pecorino (a), Gouda (b), and ewes' ripe (c) cheese samples during ripening. M: months. 


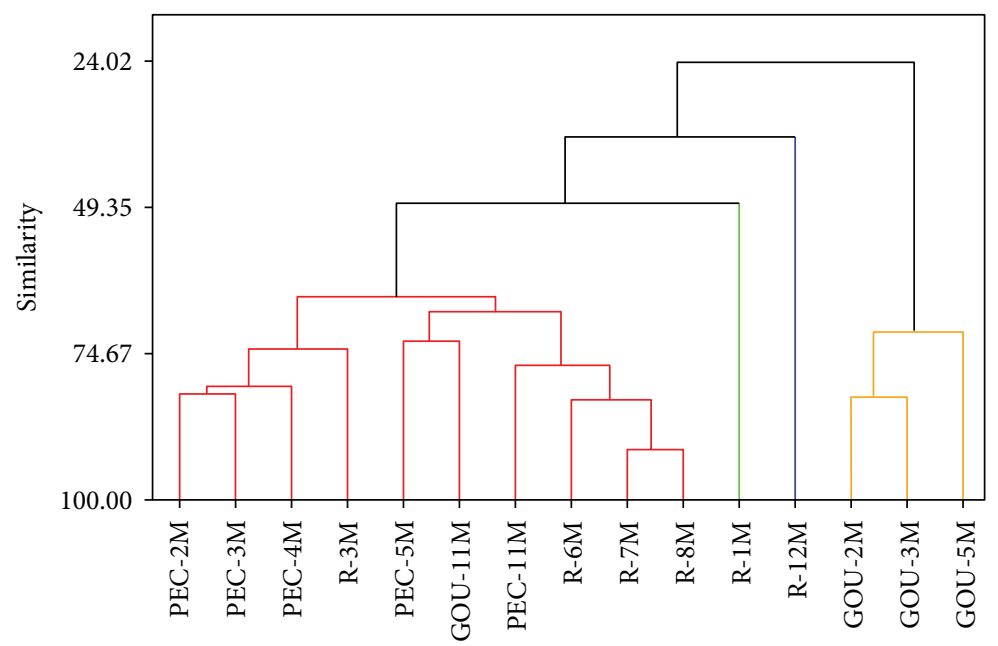

FIgURE 4: Hierarchical cluster analysis of the 15 samples of Pecorino (PEC), Gouda (GOU), and ewes' ripe (R) varieties of cheese. The ripening times are represented by its number followed by $\mathrm{M}$ (months).

$[29,32-34]$. Therefore, since the cheeses studied here had different maturation times and were produced with different batches of milk, the factors mentioned above may have influenced the proteolysis process in different ways.

Farkye and Fox [35] stated that for the most of the semihard and hard cheeses, the proteolysis process is commonly used as a ripening index. Thus, through the behavior and evolution of the peaks obtained in the FTIR/ATR spectra, the technique can be extremely useful to verify the occurrence of the proteolysis phenomenon during the cheese ripening.

3.2.2. Lipid and Carbohydrate Regions. Figure 3 shows three peaks associated with the lipid fraction. According to Dufour et al. [28], the determination of fat is commonly used by the association of the $\mathrm{C}=\mathrm{O}\left(\sim 1750 \mathrm{~cm}^{-1}\right)$ group and acyl chain C-H (3000-2800 $\left.\mathrm{cm}^{-1}\right)$ stretch wavenumbers. In Figure 3, in general, the signal of methylene peaks (bands around 2922 and $2852 \mathrm{~cm}^{-1}$ ) and those associated with ester and organic acid carbonyl $\left(\nu \mathrm{C}=\mathrm{O}\right.$ in $\left.1743 \mathrm{~cm}^{-1}\right)$ have decreased as the cheeses matured. Similar behavior was found by Martín-del-campo et al. [29]. However, the cheeses with ripening time of 5 months (Pecorino), 5 months (Gouda), and 3 months (ewes' ripe) have shown the highest absorbance bands. According to Ticiani et al. [36], at the highest lactation stage, the ewes lose the ability of keeping the fat content stable. A study developed by Brito et al. [37] showed that the ewes raised in Brazil have the peak of lactation occurring in spring (Sept-Nov), with increased fat content of the milk in approximately $2.5 \%$. Once the above-mentioned cheeses were made during the springtime, the deviation observed in the absorbance peaks may rely in the fluctuations of fat content during the peak of the lactation.

Collins et al. [38] stated that lipolysis occurs in most or all cheeses, but its intensity is more extensive in some hard Italian varieties and in Blue cheese. In addition, regarding the ripening of Cheddar, Gouda, and Swiss cheeses, the contribution of lipolysis is relatively low. Thus, among the cheese varieties studied here, the Gouda made with ewes' milk was the one that has had the least influence of lipolysis and smaller decreases in absorption during its maturation process (Figure 3(b)).

The peaks located around $1377 \mathrm{~cm}^{-1}\left(\delta_{s} \mathrm{CH}_{3}\right)$ are assigned to glucose and galactose. Surrounding $1161 \mathrm{~cm}^{-1}$ are located peaks related to the sum of lactose (tertiary alcohol $v \mathrm{C}-\mathrm{OH}$ ) and monosaccharide (endocyclic oxygen $v \mathrm{C}-\mathrm{O}$ ) signals (Figure 1) [29]. The evolution of these peaks during the ripening process has shown a similar behavior as the lipid bands, that is, a decrease in the absorbance values.

3.3. Ripening Time Discrimination by Multivariate Analysis. The different cheeses and the correspondent ripening times were submitted to the multivariate approaches HCA and PCA to observe similarity patterns and possible correlations amongst the samples. The wavenumber range used for multivariate analysis was chosen to include a wide variety of chemical groups. The spectra were subdivided in two parts: one containing information regarding amide groups, alkanes, carbon-oxygen ester bonds (between 1700 and $1000 \mathrm{~cm}^{-1}$ ), and another with wavenumbers characterized with absorption peaks typical of lipid sources $\left(3000-2800 \mathrm{~cm}^{-1}\right.$ and $1765-1730 \mathrm{~cm}^{-1}$ ) [22, 39].

Figure 4 shows the resulting dendrogram of the cluster analysis that compared the different cheese types and ripening times to obtain the similarities regarding their spectra. It was possible to observe a clear separation of the early stage samples among the 3 cheese types. A small cluster containing the earliest Gouda samples was the one that revealed to be less similar. Regarding the ewes' ripe cheese, the 1st month of maturation and the 12th month were related despite their differences. The other samples of ewes' ripe cheese, in between the 1st and 12th month, were closely related with Pecorino samples and the 11th maturation month of Gouda. These samples were all grouped together in a large cluster. The similarities between the oldest Pecorino (11 months of maturation) and Gouda (11 months of maturation), with the intermediate months of the ewes' ripe variety, suggest that the different ways that the cheeses were processed did 


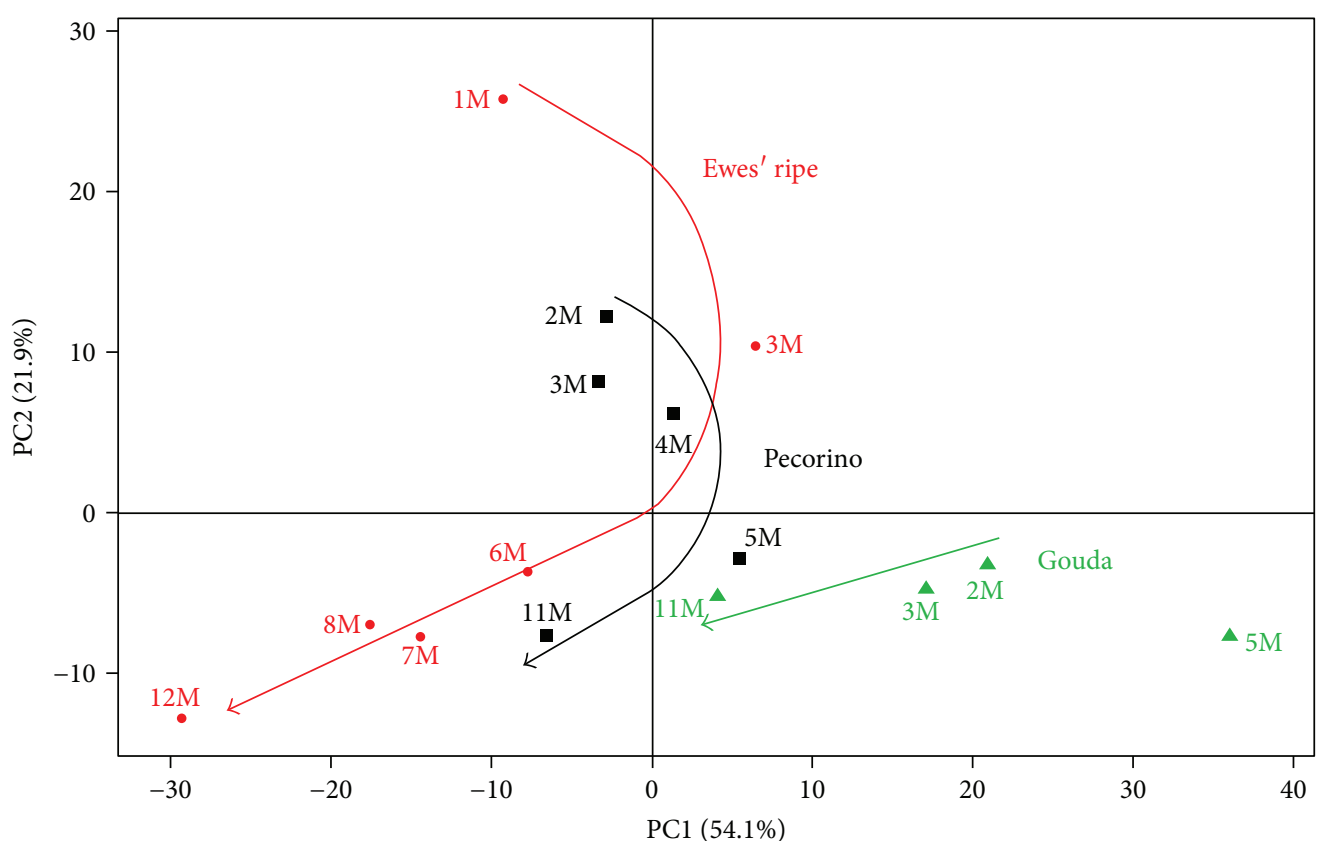

(a)

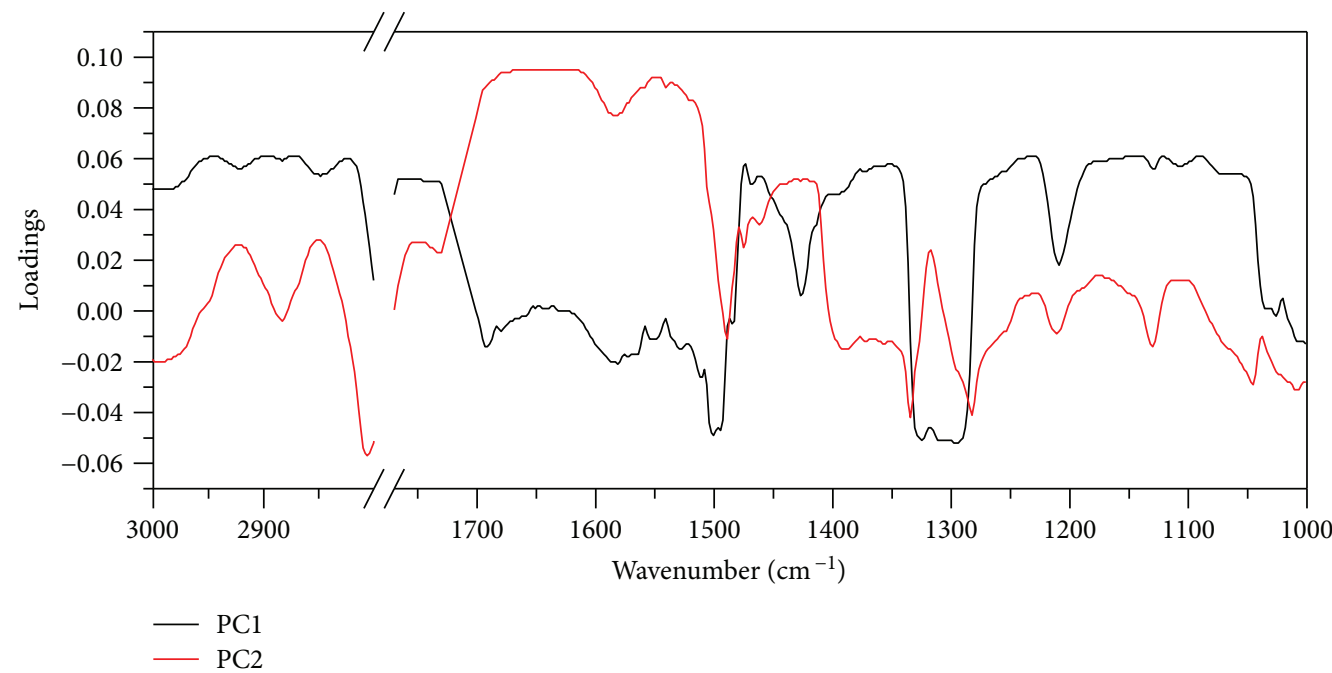

(b)

FIGURE 5: Principal component analysis of the selected wavelength spectra of the 15 samples of Pecorino ( $\boldsymbol{\square})$, Gouda ( $(\boldsymbol{\Delta})$, and ewes' ripe varieties of cheese. (a) Score plot. (b) Loading plot. M: months.

not affect the physicochemical reactions driving the maturation of the cheeses.

PCA analysis resulted in PC1 and PC2 describing above $75 \%$ of total variance of the spectra (Figure 5(a)). A separation between the different cheeses and their ripening times agreed with the pattern obtained with cluster analysis. In relation to PC1 (54.1\% of total variance), the main difference was regarding the Gouda and ewes' ripe cheeses. PC2 accounted for $21.9 \%$ of the variance of the data. In the loading plot (Figure 5(b)), the spectral region linked to lipids $\left(3000-2800 \mathrm{~cm}^{-1}\right)$ and other chemical groups related to carbohydrates and to the fingerprint of the samples (1280$1000 \mathrm{~cm}^{-1}$ ) weighted positively to $\mathrm{PC1}$, while the region associated to ester groups $\left(1330-1280 \mathrm{~cm}^{-1}\right)$ and proteins $\left(1700-1500 \mathrm{~cm}^{-1}\right)$ was present in opposition. The PC2 on the other hand seemed to be more related to bonds linked to proteins, where more intense loadings were obtained.

Regarding Pecorino cheese, the samples of the 2nd and 3rd months of maturation were correlated to both PCs. Next to them was also located at the sample of the 4 th month. The amide I and II regions were the main responsible for that proximity according to the loading plot (Figure 5(b)). The higher levels of proteolysis during the ripening of this cheese led to a decrease in number of peptide bonds (Figure 2(a)). The samples of the 5th and 11th months of Pecorino cheese were not well correlated in relation to PC1, and there was a significant difference between the earliest samples in relation to PC2. The 5th-month sample revealed high absorbance 
levels in the peaks assigned to lipids (Figures 3(a) and 5(a)). The altered profile observed in this sample might be related, as already mentioned, to the changes in the milk fat level during the lactation period.

The Gouda cheese samples were all well correlated in relation to the $\mathrm{PC} 2$, while on $\mathrm{PC} 1$, the most variability between them could be explained. PCA validated the spectral observations, where the protein region was not significantly different as in the other cheeses (Figures 2(b) and 5(a)). In case of the peaks linked to lipids (Figure 3(b)), the Gouda samples showed higher absorbance values compared to the other cheeses (Figures 3(a) and 3(c)). This fact corroborates with the positioning of these samples on the positive scale of PC1. The positioning of the 5th month of Gouda might be related with the same issue observed on Pecorino's.

In the ewes' ripe cheeses (Figure 5(a)), the lipolysis was the main reason for the variability of the samples. The lipid region, which was linked to $\mathrm{PC} 1$, showed a reduction pattern, except for the sample of the 3rd month that might have also been affected by the fat content deviation during the lactation stage (Figure 3(c)). Regarding PC2, the sample of the 1st and 3 rd months, on the other hand, revealed the highest peaks in the protein region (Figure 2(c)). These wavenumbers, once again, weighted significantly to the earliest samples, just as in Pecorino cheese.

Different authors also have demonstrated discrimination between different cheeses by means of PCA [29, 32, 40]. They have found a link between ripening and absorbance changes of amide I and II bands studying the earliest stages of ripening; however, the changes observed were not as evident as the ones found in this study.

Our results agreed to the fact that proteolysis and lipolysis are the main factors driving the maturation of cheeses. A timeline could be observed in relation to both principal components, and a trendline of the ripening process was drawn in Figure 5(a). It was concluded that the proteolysis was more intense during the earliest stages up to the end of the first trimester. Thus, different cheese types and maturation times resulted in different spectral information which must be analyzed with caution during the association with ripening index of cheeses.

\section{Conclusions}

In this study, we have interpreted and differentiated cheeses during long maturation times by means of midinfrared spectroscopy technique (FTIR-MIR-ATR). The main factors influencing the ripening process (lipolysis and proteolysis) were stressed by multivariate analysis. The infrared spectroscopy proved to be efficient on following the changes in time occurring in the cheeses regarding proteolysis and lipolysis during the maturation period. Therefore, FTIR shows potential to assist in the quality control of dairy products. While evaluating the maturation degree, the method can be envisaged with the robustness of the chemometric tools. Implemented in dairy plants, the FTIR/ATR will allow automation of the cheese ripening process without the need of sample treatment as well as subsidize a better understanding about their shelf life.

\section{Additional Points}

Highlights. (i) Ripening of special ewes' cheeses was evaluated over 1 year via FT-MIR-ATR. (ii) Proteolysis and lipolysis were well characterized throughout ripening process. (iii) HCA and PCA of the spectra clearly separated the ripening times of the samples. (iv) A timeline relationship between major molecular changes and ripening was built

\section{Conflicts of Interest}

The authors declare that they have no conflicts of interest.

\section{Acknowledgments}

This work was funded by Coordenação de Aperfeiçoamento de Pessoal de Nível Superior (CAPES) foundation (Ministry of Education of Brazil, Brasilia, DF), Fundação de Amparo à Pesquisa de Minas Gerais (FAPEMIG) foundation, Brazil, and Conselho Nacional de Desenvolvimento Científico e Tecnológico (CNPq), Brazil. The authors also thank CAPES foundation regarding the bursaries provided to Jonathan Andrade, Cristina Guimarães Pereira, and Thamiris Ranquine.

\section{References}

[1] FAOSTAT, Statistics Database, Food and Agriculture Organization of the United Nations, 2014, http://www.fao.org/ faostat/en/.

[2] USDA, Dairy: World Markets and Trade, United States Department of Agriculture, Washington DC, USA, 2016.

[3] Milkpoint, "Abiq: mercado de queijos tem alto potencial de crescimento no Brasil," 2017, January 2018, https://www .milkpoint.com.br/noticias-e-mercado/giro-noticias/abiqmercado-de-queijos-tem-alto-potencial-de-crescimento-nobrasil-105515n.aspx.

[4] M. Bergamaschi, E. Aprea, E. Betta et al., "Effects of dairy system, herd within dairy system, and individual cow characteristics on the volatile organic compound profile of ripened model cheeses," Journal of Dairy Science, vol. 98, no. 4, pp. 2183 2196, 2015.

[5] P. Mcsweeney and M. Sousa, "Biochemical pathways for the production of flavour compounds in cheeses during ripening: a review," Le Lait, vol. 80, pp. 293-324, 2000.

[6] P. F. Fox, T. P. Guinee, T. M. Cogan, and P. L. H. McSweeney, Fundamentals of Cheese Science, 2000.

[7] M. J. Sousa, Y. Ardö, and P. L. H. McSweeney, "Advances in the study of proteolysis during cheese ripening," International Dairy Journal, vol. 11, no. 4-7, pp. 327-345, 2001.

[8] V. K. Upadhyay, P. L. H. McSweeney, A. A. A. Magboul, and P. F. Fox, "Proteolysis in cheese during ripening BT - starter cultures: general aspects," 2004, http://www.sciencedirect. com/science/article/pii/S1874558X04800769\%5Cn(null).

[9] V. Fallico, P. L. H. McSweeney, K. J. Siebert, J. Horne, S. Carpino, and G. Licitra, "Chemometric analysis of proteolysis during ripening of Ragusano cheese," Journal of Dairy Science, vol. 87, no. 10, pp. 3138-3152, 2004.

[10] J.-R. Albani, Fluorescence Spectroscopy in Food Analysis, 2006. 
[11] P. L. H. McSweeney, "Biochemistry of cheese ripening," International Journal of Dairy Technology, vol. 57, no. 2-3, pp. 127144, 2004.

[12] W. W. G. Nascimento, M. P. F. de Souza, A. C. M. M. Valente, V. C. dos Anjos, M. A. M. Furtado, and M. J. V. Bell, "Results from portable and of low cost equipment developed for detection of milk adulterations," Food Science and Technology, vol. 37, pp. 38-41, 2017.

[13] M. P. Brandao, M. Gouvea Neto, V. C. dos Anjos, and M. J. V. Bell, "Detection of adulteration of goat milk powder with bovine milk powder by front-face and time resolved fluorescence," Food Control, vol. 81, pp. 168-172, 2017.

[14] M. P. Brandao, V. de Carvalho dos Anjos, and M. J. V. Bell, "Time resolved fluorescence of cow and goat milk powder," Spectrochimica Acta Part A: Molecular and Biomolecular Spectroscopy, vol. 171, pp. 193-199, 2017.

[15] R. Alves da Rocha, I. M. Paiva, V. Anjos, M. A. M. Furtado, and M. J. V. Bell, "Quantification of whey in fluid milk using confocal Raman microscopy and artificial neural network," Journal of Dairy Science, vol. 98, no. 6, pp. 35593567, 2015.

[16] M. P. Brandao, A. P. Carmo, M. J. V. Bell, and V. C. Anjos, "Characterization of milk by infrared spectroscopy," Revista do Instituto de Laticínios Cândido Tostes, vol. 373, pp. 30-33, 2010.

[17] W. Horwitz and G. W. Latimer, Official Methods of Analysis of AOAC International, Association of Official Analytical Chemistry International, Gaithersburg, MD, USA, 18th edition, 2005.

[18] I. González-Martín, J. M. Hernández-Hierro, R. Morón-Sancho, J. Salvador-Esteban, A. Vivar-Quintana, and I. Revilla, "Determination of the percentage of milk (cow's, ewe's and goat's) in cheeses with different ripening times using near infrared spectroscopy technology and a remote reflectance fibre-optic probe," Analytica Chimica Acta, vol. 604, no. 2, pp. 191-196, 2007.

[19] I. González-Martín, J. M. Hernández-Hierro, A. VivarQuintana, I. Revilla, and C. González-Pérez, "The application of near infrared spectroscopy technology and a remote reflectance fibre-optic probe for the determination of peptides in cheeses (cow's, ewe's and goat's) with different ripening times," Food Chemistry, vol. 114, no. 4, pp. 1564-1569, 2009.

[20] M. J. Lerma-García, A. Gori, L. Cerretani, E. F. Simó-Alfonso, and M. F. Caboni, "Classification of Pecorino cheeses produced in Italy according to their ripening time and manufacturing technique using Fourier transform infrared spectroscopy," Journal of Dairy Science, vol. 93, no. 10, pp. 4490-4496, 2010.

[21] H. Kraggerud, T. Næs, and R. K. Abrahamsen, "Prediction of sensory quality of cheese during ripening from chemical and spectroscopy measurements," International Dairy Journal, vol. 34, no. 1, pp. 6-18, 2014.

[22] L. E. Rodriguez-Saona, N. Koca, W. J. Harper, and V. B. Alvarez, "Rapid determination of Swiss cheese composition by Fourier transform infrared/attenuated total reflectance spectroscopy," Journal of Dairy Science, vol. 89, no. 5, pp. 1407-1412, 2006.

[23] A. Subramanian, V. B. Alvarez, W. J. Harper, and L. E. Rodriguez-Saona, "Monitoring amino acids, organic acids, and ripening changes in Cheddar cheese using Fouriertransform infrared spectroscopy," International Dairy Journal, vol. 21, no. 6, pp. 434-440, 2011.

[24] J. O. A. do Amarante, Queijos do Brasil e do Mundo: para iniciantes e apreciadores, Mescla Editorial, São Paulo, 2015.

[25] I. A. Lutz, Métodos Físico-Químicos para Análise de Alimentos, 4th edition4th edition, , 2004.

[26] BRASIL, Instrução Normativa no 68 de 12/12/2006. Oficializa os Métodos Analíticos Oficiais Físico-Químicos, para Controle de Leite e Produtos Lácteos, Diário Oficial da República Federativa do Brasil, 2006.

[27] BRASIL, Portaria No. 146 de 07 de março de 1996. Aprovar os Regulamentos Técnicos de Identidade e Qualidade dos Produtos Lácteos, Diário Oficial da República Federativa Do Brasil, 1996.

[28] E. Dufour, G. Mazerolles, M. F. Devaux, G. Duboz, M. H. Duployer, and N. Mouhous Riou, "Phase transition of triglycerides during semi-hard cheese ripening," International Dairy Journal, vol. 10, no. 1-2, pp. 81-93, 2000.

[29] S. T. Martín-del-Campo, D. Picque, R. Cosío-Ramírez, and G. Corrieu, "Middle infrared spectroscopy characterization of ripening stages of Camembert-type cheeses," International Dairy Journal, vol. 17, no. 7, pp. 835-845, 2007.

[30] P. L. H. McSweeney, "Biochemistry of cheese ripening: introduction and overview," Cheese: Chemistry, Physics and Microbiology, vol. 1, pp. 347-360, 2004.

[31] A. Subramanian and L. Rodriguez-Saona, "Chapter 7 - fourier transform infrared (FTIR) spectroscopy," in Infrared Spectroscopy for Food Quality Analysis and Control, D.-W. Sun, Ed., pp. 145-178, Academic Press, San Diego, CA, USA, 2009.

[32] G. Mazerolles, M.-F. Devaux, G. Duboz, M.-H. Duployer, N. Mouhous Riou, and E. Dufour, "Infrared and fluorescence spectroscopy for monitoring protein structure and interaction changes during cheese ripening," Le Lait, vol. 81, no. 4, pp. 509-527, 2001.

[33] A. Kulmyrzaev, É. Dufour, Y. Noël et al., "Investigation at the molecular level of soft cheese quality and ripening by infrared and fluorescence spectroscopies and chemometrics - relationships with rheology properties," International Dairy Journal, vol. 15, no. 6-9, pp. 669-678, 2005.

[34] L. Vannini, D. Baldi, and R. Lanciotti, "Use of Fourier transform infrared spectroscopy to evaluate the proteolytic activity of Yarrowia lipolytica and its contribution to cheese ripening," International Journal of Food Microbiology, vol. 69, no. 1-2, pp. 113-123, 2001.

[35] N. Y. Farkye and P. F. Fox, "Objective indices of cheese ripening," Trends in Food Science \& Technology, vol. 1, pp. 37-40, 1990.

[36] E. Ticiani, E. C. Sandri, J. De Souza, F. Batistel, and D. E. De Oliveira, "Persistência da lactação e composição do leite em ovelhas leiteiras das raças Lacaune e East Friesian," Ciência Rural, vol. 43, no. 9, pp. 1650-1653, 2013.

[37] M. A. Brito, F. D. González, L. A. Ribeiro et al., "Composição do sangue e do leite em ovinos leiteiros do sul do Brasil: variações na gestação e na lactação," Ciência Rural, vol. 36, no. 3, pp. 942-948, 2006.

[38] Y. F. Collins, P. L. H. McSweeney, and M. G. Wilkinson, "Lipolysis and free fatty acid catabolism in cheese: a review of current knowledge," International Dairy Journal, vol. 13, no. 11, pp. 841-866, 2003. 
[39] D. A. Skoog, F. J. Holler, and S. R. Crouch, Principles of Instrumental Analysis, vol. 152Thompson Brooks/Cole, 6th edition, 2006.

[40] G. Mazerolles, M. F. Devaux, E. Dufour, E. M. Qannari, and P. Courcoux, "Chemometric methods for the coupling of spectroscopic techniques and for the extraction of the relevant information contained in the spectral data tables," Chemometrics and Intelligent Laboratory Systems, vol. 63, no. 1, pp. 57-68, 2002. 

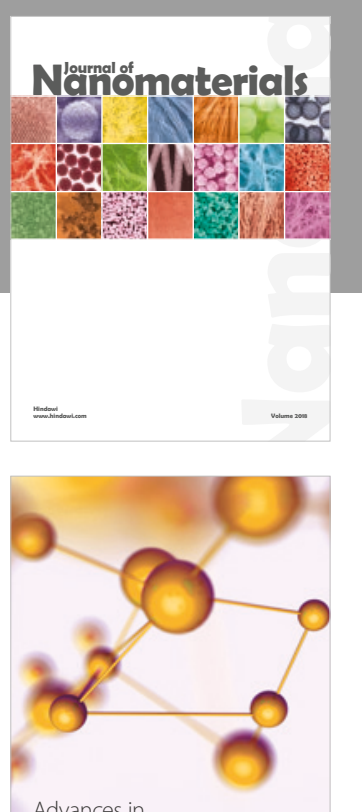

Physical Chemistry
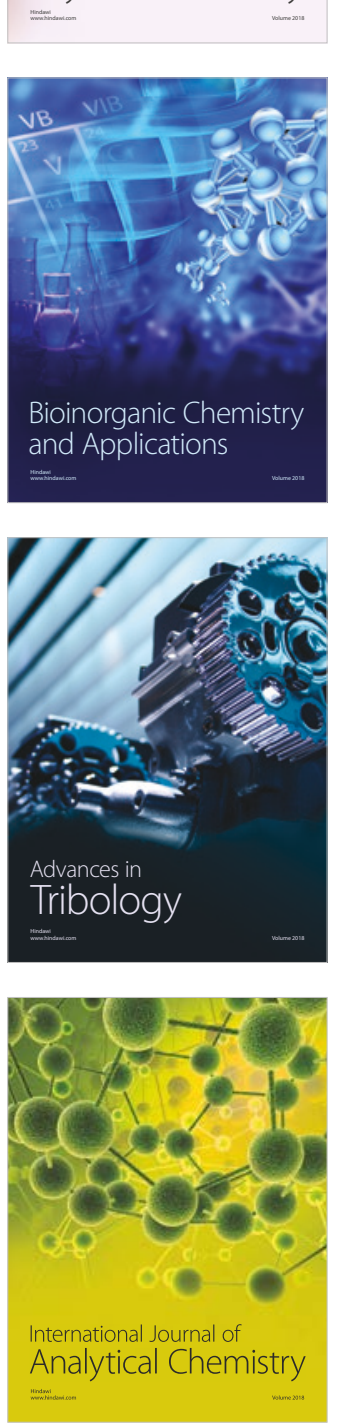

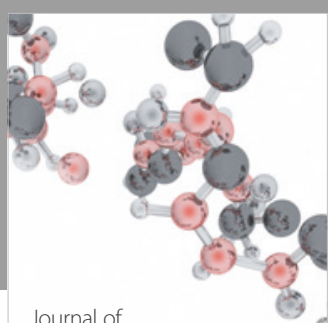

Analytical Methods

in Chemistry

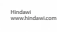

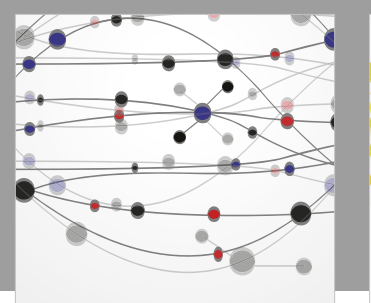

The Scientific World Journal

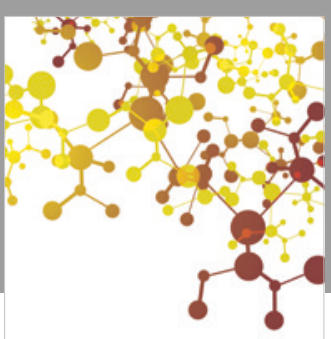

Journal of

Applied Chemistry
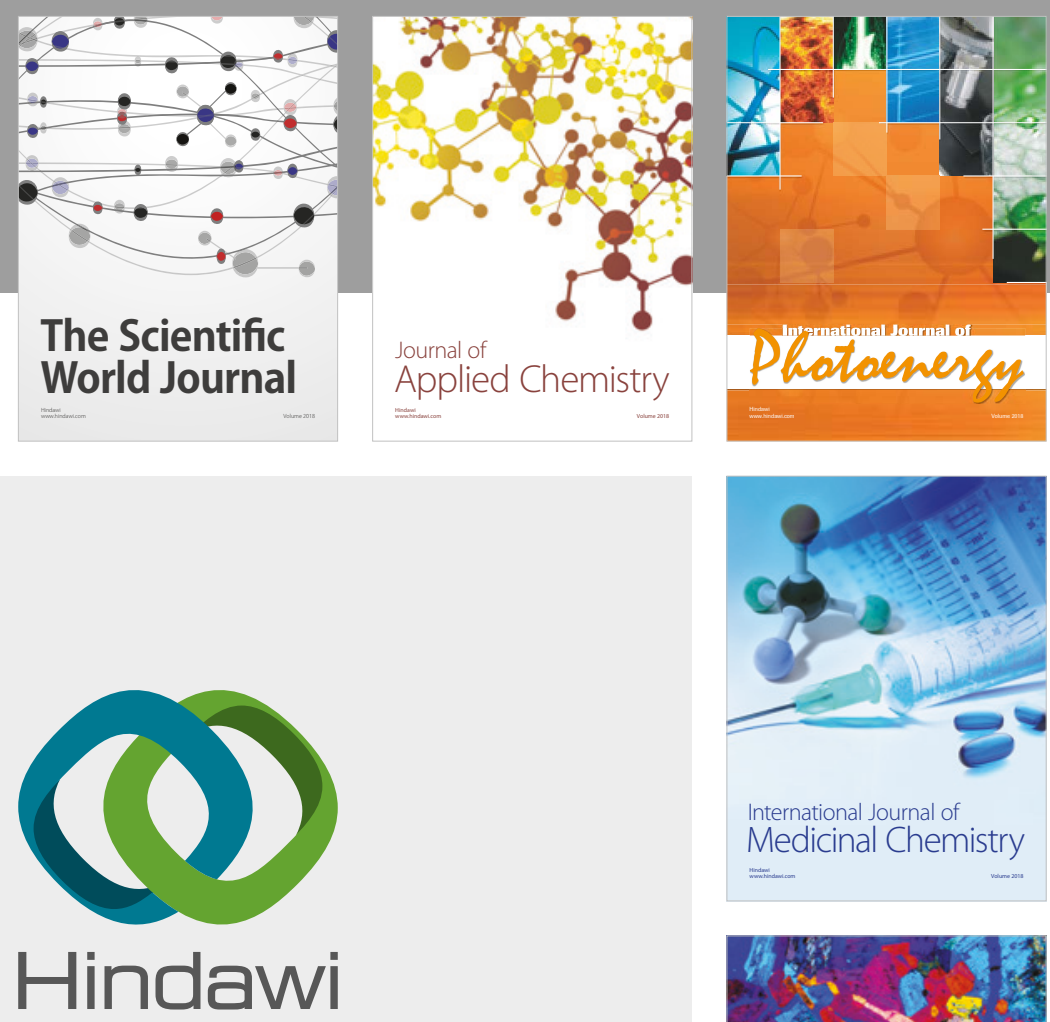

Submit your manuscripts at

www.hindawi.com
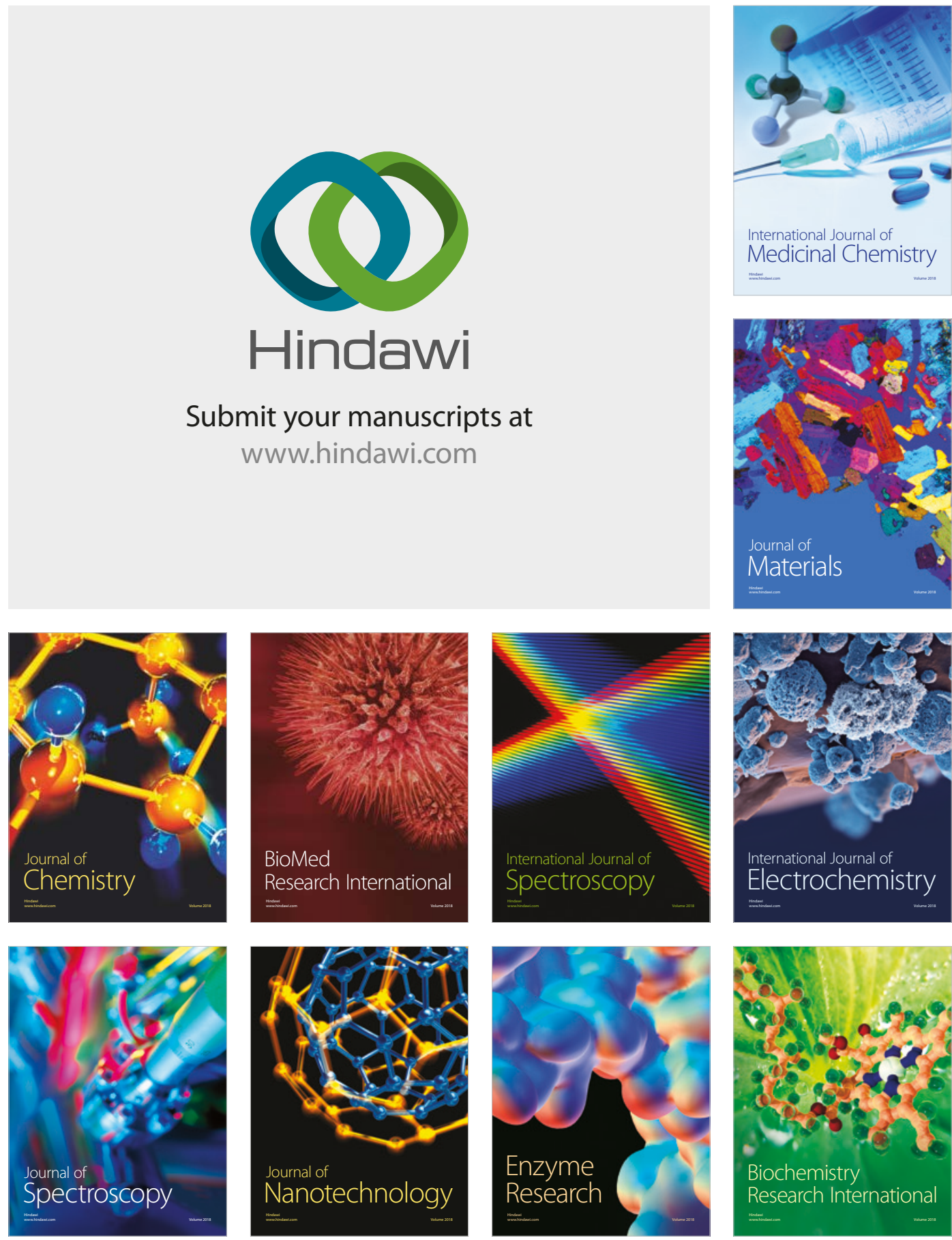
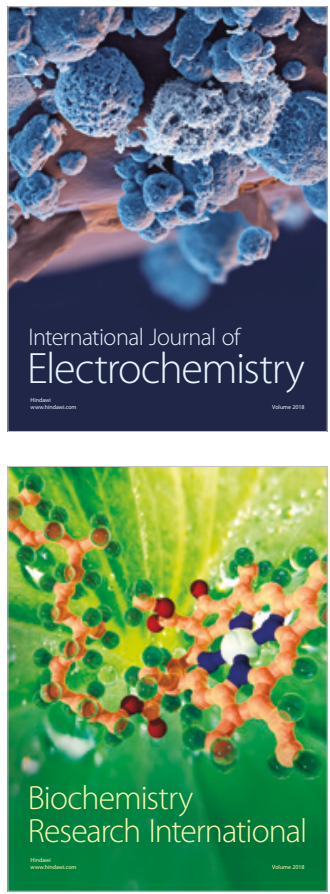